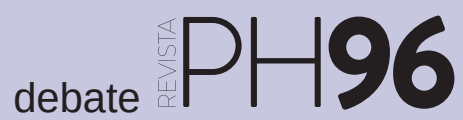

a debate Memoria democrática en la construcción de la historia y el patrimonio

| coordina Josefina Cuesta Bustillo

\title{
Memoria democrática y verdad
}

Jorge Benavides Solís | Dpto. de Urbanística y Ordenación del Territorio, Universidad de Sevilla

URL de la contribución <www.iaph.es/revistaph/index.php/revistaph/article/view/4284>

En los textos de invitación y forma de participar en el "debate", constato que se trata de reflexionar sobre la forma de cómo hacer operativos y prácticos los objetivos del artículo cuatro de la Ley $2 / 2017$, en el cual se precisa lo que se entiende por memoria democrática en Andalucía. En consecuencia, no es un debate (controversia) teórico acerca de la memoria, tal como la asume la Filosofía (RECOEUER, 1998; TODOROV, 2013), de la memoria colectiva, según la entendió y acuñó Halbwachs (París, 1950) o la Psicología Social (VÁZQUEZ, 2001). Siendo así, no hay espacio para el debate sino para un enriquecedor intercambio de ideas dirigidas no a justificar sino a cumplir con los propósitos de la Ley, para el mayor y mejor beneficio de la sociedad.

Con razón en la introducción al debate se dice que la "memoria colectiva se distingue de la historia" pero no está desvinculada de ésta (memoria histórica). Se trataría de ver cómo vincularlas recurriendo a la democracia; sin embargo, quizá hubiese sido mejor aproximarla al derecho universal, a la verdad (RESOLUCIÓN, 2005) porque ésta es menos relativa que la democracia.

La invitación al "debate" parte de un contenido con certidumbre implícita sobre la función de la historia y de la democracia que no se inscribe en el específico ámbito del patrimonio cultural o, mejor aún, de la herencia cultural por cuya protección vela el IAPH, sino de las diversas formas de gobierno entre las cuales se destaca la democracia, sin distinción de grados o de calidades. $\mathrm{Ni}$ las elecciones ni las leyes, que en el mundo la regulan y le posibilitan realizarse, son similares. Los historiadores y los gobiernos no hacen la historia. Eso sí, unos la interpretan y la escriben, otros la utilizan.

No hay democracias perfectas sino perfectibles porque, además, no son puntos de llegada sino procesos dependientes de múltiples variables con inciertos comportamientos. Actualmente, Estados Unidos goza de una democracia menos imperfecta que la de España o Rusia. En Cuba no está vigente el modelo europeo de democracia formal. En numerosos países no hay democracia y además no hay libertad, ni de pensamiento ni de acción (Arabia Saudita). Cosa parecida sucede en China y en numerosos países más. Pero todos protegen, a su manera, su herencia cultural, el patrimonio de todos, pero ignoran el significado y el contenido de la ciudadanía. Sin embargo, todos sus habitantes tienen derecho a la verdad.

La calidad de la democracia como forma de gobierno no está en directa proporción al grado de protección del patrimonio cultural, sino de otros factores y componentes. En cualquier caso eso sí, la posibilidad que se tenga para el ejercicio proactivo de la ciudadanía garantizará un mayor cuidado de la herencia cultural y una democracia de mejor calidad.

Sin embargo, si se habla de una específica memoria democrática, el asunto se inscribe, por una parte, en un ámbito del poder político (administrativo) que puede llegar a concretarse en leyes de amnistías y olvidos; y, por otra parte, en un ámbito concreto de trascendencia social y humana, si se toman en cuenta los asesinatos y las acciones legales de las dictaduras, de legitimidad dudosa en un periodo histórico y circunstancial (Andalucía).

En base a dichas consideraciones, convendría tomar como referencia comparativa las formas integralmente positivas de rescatar, hacer ostensible y difundir los resultados de una experiencia histórica negativa en otros países. Más específicamente con los que han sufrido las consecuencias de las nefastas acciones de las dictadu- 
a debate Memoria democrática en la construcción de la historia y el patrimonio

| coordina Josefina Cuesta Bustillo

\begin{tabular}{|lll}
\hline País & Años con dictadura & Leyes de amnistía \\
\hline Italia (Mussolini) & $1922-1943$ & D. Presidencial Togliatti junio/42 \\
\hline Portugal (Salazar) & $1933-1974$ & Acciones rupturistas con la dictadura \\
\hline Alemania (Hitler) & $1933-1945$ & Eliminación de símbolos nazistas \\
\hline España (Franco) & $1936-1975$ & Ley 46/1977 \\
\hline Chile (Pinochet) & $1973-1990$ & $\begin{array}{l}\text { La Comisión Nacional de Verdad y Reconciliación. Decreto Supremo 355 1990. } \\
\text { Informe Rettig 1991 }\end{array}$ \\
\hline Argentina (militares) & $1975-1983$ & $\begin{array}{l}\text { Ley de Punto Final Dic/1986. Corte Suprema declara inconstitucional indultos y } \\
\text { Leyes de Obediencia Debida y Punto Final, 2001 }\end{array}$ \\
\hline
\end{tabular}

ras en sus países, ahora con gobiernos democráticos (ver tabla adjunta).

La eliminación del prójimo por razones de guerra es una constante no superado por el "sapiens". Las sentencias de muerte por razones políticas, también. Incluso aplicada a las personas que únicamente han pensado (Sócrates, Cristo). Otro matiz tiene la represión del poder para imponer su voluntad omnímoda apoyada en dogmas o principios impuestos no discutibles de todo tipo: económicos, raciales, religiosos (inquisición, holocausto judío, genocidio armenio). En este último ámbito se inscribe el gobierno franquista, dictadura de similar comportamiento a otras: los dictadores eliminaron a miles de ciudadanos opositores a su régimen por pensamiento, palabra u obra.

Los espacios públicos en países reprimidos, con frecuencia, son convertidos en escenarios de la muerte como advertencia pedagógica (Irán, París de la Revolución Francesa, etc.).

En suma, la recuperación y la elaboración de la memoria colectiva, en términos operativos, tal como plantea el "debate", es responsabilidad de la administración. Las acciones para su recuperación, en todos los casos, deberían estar próximas a la verdad y al ejemplar comportamiento de los políticos. Convendría retirar los símbolos de los espacios públicos pero no la información histórica si los acompañan. Es el caso de las placas en obras civiles y edificios construidos en el período franquista: año y proyectista.

\section{BIBLIOGRAFÍA}

- HALBWACHS, M. (1950) La mémoire collective. Paris: Presses Universitaires de France, 1950

- RESOLUCIÓN 2005/66 sobre "EL DERECHO LA VERDAD"(2005) 59.a Sesión de la Comisión de Derechos Humanos de Naciones Unidas. 20 de abril de 2005

- RICOEUR, P. (1998) La lectura del tiempo pasado: memoria y olvido. Madrid: Arrecife Producciones, 1998

- TODOROV, T. (2013) Los abusos de la memoria. Barcelona: Paidós Ibérica, 2013

- VÁZQUEZ, F. (2001) La memoria como acción social. Barcelona: Paidós, 2001 